\title{
Evaluation of the Physico-Chemical Quality and Potability of Groundwater Consumption in Department of Collines at Benin
}

\author{
Okoundé Kotchikpa Jean-Eudes ${ }^{*}$, Ringo Fernand Avahounlin ${ }^{1,2}$, Carine Nelly Kélomé3, \\ Ouassa Pierre',4, Adjoa Mirande Hermione Adéké1, Expédit Wilfried Vissin ${ }^{4}$ \\ ${ }^{1}$ Chaire Internationale de Physique Mathématique et Applications (CIPMA CHAIRE-UNESCO, FAST, UAC), Cotonou, Benin \\ ${ }^{2}$ Ecole Normale Supérieure (ENS, UNSTIM), Natitingou, Benin \\ ${ }^{3}$ Département des Sciences e la Terre, Université d'Abomey-Calavi, Benin \\ ${ }^{4}$ Département de Géographie et Aménagement du Territoire (DGAT, FASHS, UAC), Cotonou, Benin \\ Email: ‘jkoutchikpa@gmail.com, allouboss@gmail.com, nkelome@yahoo.fr, ouaspeter@gmail.com, admir91@yahoo.com, \\ exlaure@gmail.com
}

How to cite this paper: Jean-Eudes, O. K., Avahounlin, R. F., Kélomé, C. N., Pierre, O., Adéké, A. M. H., \& Vissin, E. W. (2022). Evaluation of the Physico-Chemical Quality and Potability of Groundwater Consumption in Department of Collines at Benin. Journal of Geoscience and Environment Protection, 10, 29-48.

https://doi.org/10.4236/gep.2022.101003

Received: January 25, 2021

Accepted: January 7, 2022

Published: January 10, 2022

Copyright $\odot 2022$ by author(s) and Scientific Research Publishing Inc. This work is licensed under the Creative Commons Attribution International License (CC BY 4.0).

http://creativecommons.org/licenses/by/4.0/ (c) (i) Open Access

\begin{abstract}
The purpose of this study is to assess the physical and chemical quality of borehole water intended for consumption in the collines department in Benin. At the end of a sampling campaign, twenty-one (21) drinking water points were sampled. Different physico-chemical parameters were measured using standard analysis methods. The results of the analysis of the samples, showed that the groundwater of the department of the hills is characterized by a neutral $\mathrm{pH}$ and an average electrical conductivity in accordance with the WHO and Benin standard relating to the potability of groundwater. With this $\mathrm{pH}$ neutrality which would be linked to the nature of geological formations made up of crystalline rocks, the water in the hills is moderately hard with hardness values of $208 \mathrm{mg} / \mathrm{L}$ on average for magnesium ions of $22.54 \mathrm{mg} / \mathrm{L}$ on average and calcium ions of the order of $46.03 \mathrm{mg} / \mathrm{L}$ on average at the scale of the various localities and an alkalinity is of $43.81 \mathrm{mg} / \mathrm{L}$ on average. The $\mathrm{NO}_{3}^{-}$ values between 0 and $163.91 \mathrm{mg} / \mathrm{L}$ are low in the South-East and very high, even exceeding the standard accepted by WHO in the West and North-East of the study area. This nitrate pollution and the fairly high levels of organic matter in total nitrogen observed in the groundwater of the hills could also have an impact on the vulnerability of the water table. And this pollution with nitrates associated with electrical conductivity and chloride levels modifies and degrades from one drinking water point to another the potability of underground water in the hills.
\end{abstract}




\section{Keywords}

Collines Department, Physico-Chemical Parameters, Groundwater, Physico-Chemical Parameters, Potability of Underground Water

\section{Introduction}

Benin has a significant renewable water resource potential estimated on average at 13 billion cubic meters per year for surface water and an average annual recharge of about 2 billion cubic meters for groundwater (Azonsi et al., 2009). In terms of uses, around 90 million cubic meters of water are currently withdrawn from available groundwater resources, it's mean less than $5 \%$ of the potential, while surface water reservoirs can only store one around thirty million cubic meters, or less than $0.3 \%$ of surface water resources drained by the country's hydrographic network (Directorate General for Water, DG Eau 2006). In basement regions, groundwater resources are the most in demand for the DWS because of their technically favorable and financially less costly operating conditions. Suddenly, there is strong pressure on this component that can affect its availability in quantity and quality in the medium and long term (Tossou, 2016).

In the Collines department in Benin, a region known to be hydrogeologically difficult where the drinking water supply sector is dependent on groundwater, the excessive use of chemical fertilizers and pesticides to increase agricultural yields constitutes a danger for the quality of groundwater. It should be remembered that the quantitative and qualitative composition of groundwater in dissolved and suspended matter, of mineral or organic nature, determines its quality (Jain et al., 2005) and this quality can be altered when external substances enter in contact with the aquifer. This is the case with undesirable or even toxic substances which make groundwater and surface water unsuitable and toxic for various uses, in particular for the use of drinking water (Méhounou et al., 2016).

The poor quality of drinking water is a public health problem (WHO, 1981; World Health Organization, 2006). Thus, since the different water user and consumer sectors can induce more or less negative effects on the quality of groundwater resources, it is important that this water be subject to systematic and regular analyzes of its quality. This reflects the objective of this study, which is to assess the physical and chemical quality of borehole water intended for consumption in the hills Department in Benin.

\section{Materiel and Methods}

\subsection{Hydrogeological Framework of the Study}

The Hills Department, which covers an area of $13,931 \mathrm{~km}^{2}$, is located between $7^{\circ} 27^{\prime \prime}$ and $8^{\circ} 46^{\prime \prime}$ North latitude and between $1^{\circ} 39^{\prime \prime}$ and $2^{\circ} 44^{\prime \prime}$ East longitude. Rainfall and temperature are two factors that influence the availability of water in hill towns. The rainfall regime follows a bimodal distribution in the South and 
unimodal distribution in the North (Bokonon-Ganta, 1987; Boko, 1988; Afouda, 1990; Houssou, 1998; Ogouwalé, 2006). And despite the amount of water flowing and seeping in, drinking water supply remains problematic due to the geological nature of the subsoil.

Geologically, the department of hills is located on the scale of the structural unit of the plain of Benin and presents a great complexity of geological formations affected by several phases of deformation, metamorphism and magmatism (Boukari, 1982). Figure 1 shows outcropping lithological formations. In the southern part, migmatitic and gneissic formations are exposed, intruded by granitic plutons in circumscribed masses and a volcano-sedimentary series (Breda, 1989; Adissin, 2012). These outcrops have a general north-south direction (Dubroeucq, 1967). In the Northeast, we observe in places, plutons of porphyroid granite with biotite appearing in the form of plissote massifs placed in the host gneissic to migmatitic, the North-West being dominated by migmatites and gneiss of the Pira group.

Studies (Kamagaté, 2006; Kamagaté et al., 2007; El-Fahem, 2008; Kamagaté et al., 2008) on the hydrogeology of the basement aquifers of Benin, particularly in the upper valley of the Ouémé and on the characteristics of the aquifers in the study area, particularly in its southern part in Dassa-Zoumé and its surroundings (Boukari, 1982; 2007) have shown the existence of two main reservoirs,

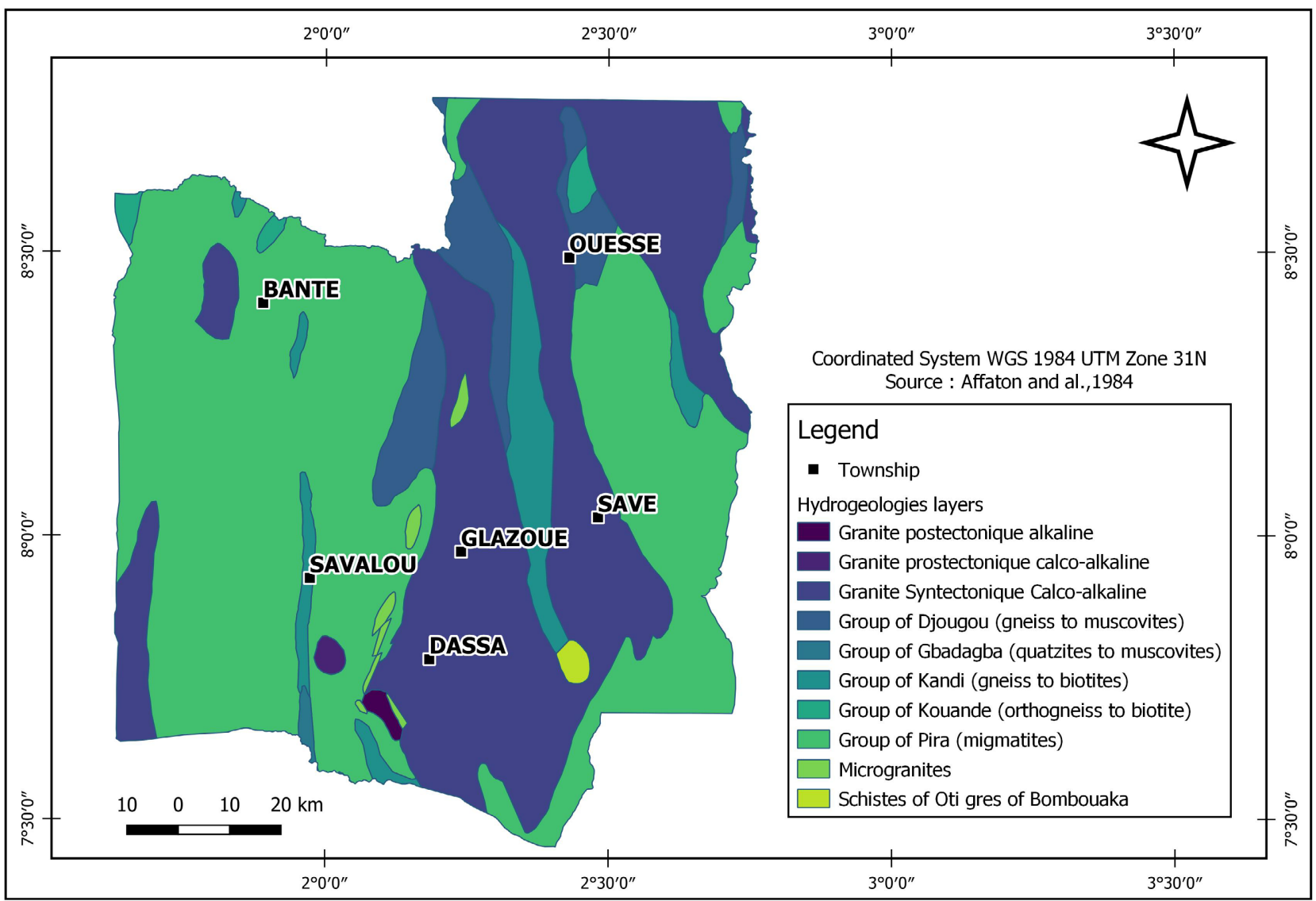

Figure 1. Geological map at the scale of the hills department. 
superimposed and in permanent contact, which characterize the study area. According to the authors, these aquifer systems are made of a superficial alterite reservoir made up of the semi-permeable alteration product of the underlying healthy rock, characterized by a good capacitive function and whose water table is fed from the surface by rainfall recharge; and an underlying reservoir of cracks and fractures allowing drainage of the upper loose cover with interstitial porosity.

\subsection{Sampling and Assay Methods}

The assessment of the physico-chemical quality of groundwater in the hills was possible using water sampling taken during a campaign in October 2019. Thus, the physico-chemical parameters measured in situ and at laboratory, were used to assess the quality of this drinking water.

\section{- Sampling}

Sampling was done at 21 water points which are boreholes intended for the drinking water supply (DWS). Figure 2 shows the spatial distribution of the sampling points. The size of the sample covers the south of the department widely. To do this, 1.5 liter plastic bottles previously washed and rinsed in the laboratory were completely filled with water. These are then hermetically sealed to prevent any gas leakage. At the same time, a $250 \mathrm{ml}$ glass beaker rinsed with

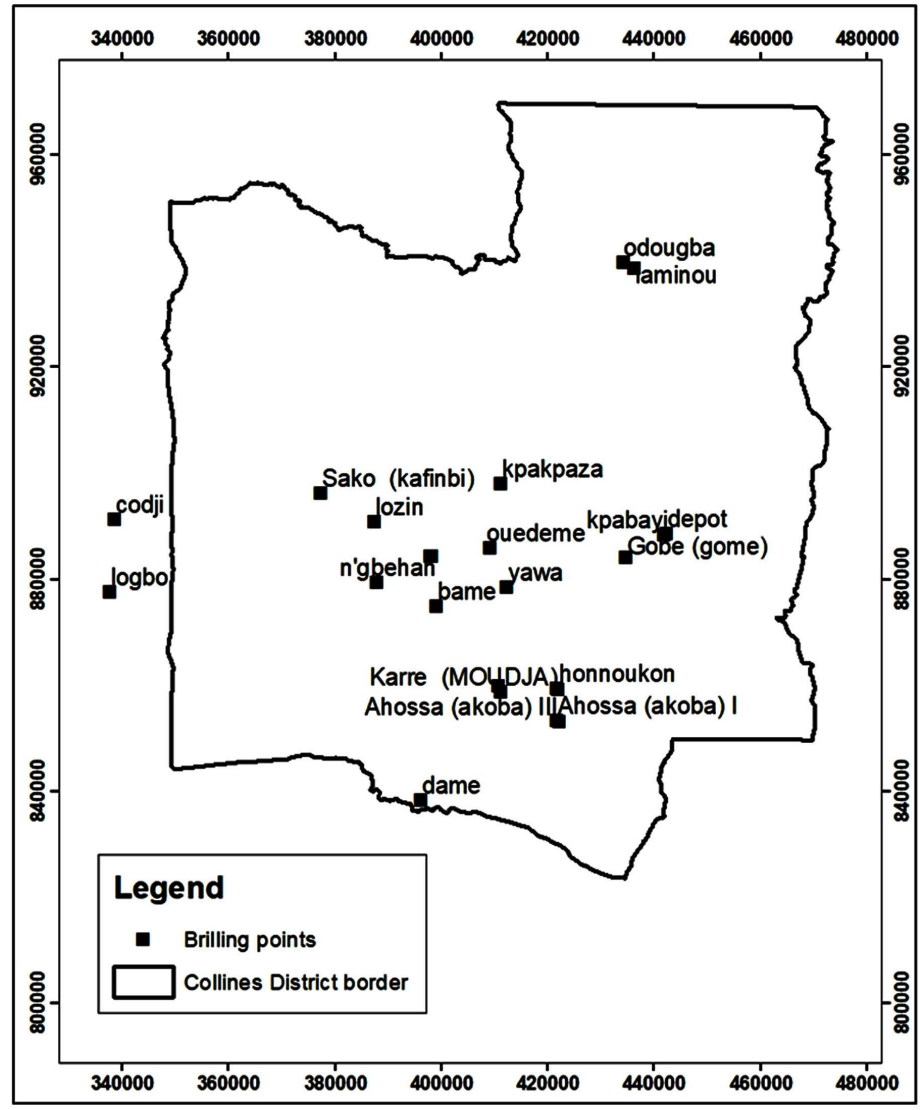

Figure 2. Spatial distribution of sampling points in the Hills. 
the water to be analyzed (before taking measurements) and with distilled water (before any new sampling) was used for in situ measurements of $\mathrm{pH}$, conductivity and TDS. Once the samples have been taken, the vials of bottles are placed in a cooler containing ice to be stored at a temperature of $4^{\circ} \mathrm{C}$ until the Central Laboratory for Water Analysis (LCAE) of the Directorate General for Water (DG-Eau); where they are kept at the same temperature until the date of analysis.

\section{- Assay methods}

The $\mathrm{pH}$, the temperature $\left(\mathrm{T}^{\circ} \mathrm{C}\right)$, the total dissolved salt (TDS) and the Electrical Conductivity (CE) were measured by a pH/Oxi meter WTW 340i whose probe rinsed and immersed in a beaker containing the sample displays on the screen and after stabilization, the relative values of the three parameters in situ.

Chemical parameters such as calcium $\left(\mathrm{Ca}^{2+}\right)$, magnesium $\left(\mathrm{Mg}^{2+}\right)$ and chloride $\left(\mathrm{Cl}^{-}\right)$are measured by the volumetric method. Other parameters including color, sulfate $\left(\mathrm{SO}_{4}^{2-}\right)$, nitrite $\left(\mathrm{NO}_{2}^{-}\right)$, nitrate $\left(\mathrm{NO}_{3}^{-}\right)$, phosphate $\left(\mathrm{PO}_{4}^{3-}\right)$, fluoride $\left(\mathrm{F}^{-}\right)$, iodide $\left(\mathrm{I}^{-}\right)$, Ammonium $\left(\mathrm{NH}_{4}^{+}\right)$and iron $\left(\mathrm{Fe}^{2+}\right)$ are made by the method of spectrometry. The assay protocols for these parameters were made by standard analysis methods as described by Rodier et al., (2009) or according to the catalogs of the equipment used.

\section{Analysis Results}

\subsection{Normalized Principal Component Analysis (ACPN)}

The statistical study carried out by ACPN gives numerous results which are presented in Table 1 and Table 2. In Table 1, are recorded the eigenvalues, the variances expressed for each factor and their accumulations. The factor F1, with an expressed variance of $47.58 \%$ is the most important of all, then the factors $\mathrm{F} 2$, F3, F4 and F5 with respectively $13.06 \%$; $10.33 \%$; $7.36 \%$; and $6.07 \%$ of the expressed variance.

These five factors reflect most of the information sought and make it possible to represent the cloud of points in a significant way because the sum of the variance expressed by these factors is $84.40 \%$. The contribution of the different variables in the definition of the main factors is given in Table 2. Each factor is defined by a certain number of essential variables in the demonstration of the mechanism of water mineralization. This table shows that the factor F1, the most important is defined by the electrical conductivity, the hardness, the alkalinity and the ions $\mathrm{Cl}^{-}, \mathrm{Mg}^{2+}, \mathrm{Ca}^{2+}, \mathrm{HCO}_{3}^{-}, \mathrm{NO}_{3}^{-}, \mathrm{SO}_{4}^{2-}$ in opposition to the ions $\mathrm{Fe}^{2+}, \mathrm{NH}_{4}^{+}, \mathrm{NO}_{2}^{-}$and $\mathrm{I}^{-}$.

Table 1. Eigenvalues and percentages expressed for the main axes.

\begin{tabular}{cccccc}
\hline & F1 & F2 & F3 & F4 & F5 \\
\hline Own value & 9.04 & 2.48 & 1.96 & 1.40 & 1.15 \\
Variance expressed (\%) & 47.58 & 13.06 & 10.33 & 7.36 & 6.07 \\
Cumulative variance expressed (\%) & 47.58 & 60.64 & 70.97 & 78.33 & 84.40 \\
\hline
\end{tabular}


Table 2. Correlations between variable and factor.

\begin{tabular}{|c|c|c|c|c|c|}
\hline & $\mathrm{F} 1$ & F2 & F3 & F4 & F5 \\
\hline $\mathrm{Ph}$ & -0.04 & 0.67 & 0.46 & -0.35 & 0.11 \\
\hline TDS & -0.91 & 0.30 & 0.01 & 0.21 & -0.02 \\
\hline $\mathrm{CE}$ & -0.92 & 0.29 & -0.02 & 0.21 & 0.01 \\
\hline $\mathrm{T},{ }^{\circ} \mathrm{C}$ & -0.29 & 0.67 & 0.43 & -0.09 & 0.10 \\
\hline Color & 0.60 & 0.18 & -0.46 & 0.13 & 0.31 \\
\hline $\mathrm{Mg}$ & -0.88 & 0.18 & -0.30 & -0.11 & 0.01 \\
\hline $\mathrm{Ca}$ & -0.89 & -0.10 & -0.18 & -0.04 & -0.02 \\
\hline $\mathrm{Cl}$ & -0.90 & 0.31 & -0.11 & 0.20 & 0.11 \\
\hline $\mathrm{HCO}_{3}$ & -0.71 & -0.17 & -0.36 & -0.42 & -0.16 \\
\hline $\mathrm{NH}_{4}$ & 0.62 & 0.58 & -0.35 & -0.14 & -0.27 \\
\hline $\mathrm{NO}_{3}$ & -0.75 & 0.12 & -0.05 & 0.11 & 0.20 \\
\hline $\mathrm{NO}_{2}$ & 0.63 & 0.53 & -0.37 & -0.09 & -0.33 \\
\hline $\mathrm{PO}_{4}$ & -0.03 & -0.22 & 0.16 & 0.46 & -0.73 \\
\hline $\mathrm{Fe}$ & 0.71 & 0.00 & -0.18 & 0.23 & 0.39 \\
\hline $\mathrm{SO}_{4}$ & -0.56 & 0.37 & 0.09 & 0.57 & -0.07 \\
\hline F & -0.28 & -0.10 & 0.74 & -0.33 & -0.12 \\
\hline I & 0.65 & 0.58 & -0.14 & -0.10 & -0.21 \\
\hline Hardness & -0.93 & 0.05 & -0.26 & -0.08 & 0.00 \\
\hline Alcalinity & -0.71 & -0.17 & -0.36 & -0.42 & -0.16 \\
\hline
\end{tabular}

Significant links existing between the different parameters are given by the correlation matrix. These links reflect the different correlations that exist between the parameters analyzed. Based on the critical correlation coefficient $r=$ 0.64 (Mangin, 1970), electrical conductivity is strongly correlated with the majority of ions $(r>0.5)$. Note that electrical conductivity (EC) describes the inorganic salts present in solution in water. The space of the variables of the factorial plane F1 - F2 (Figure 3) shows that this plane expresses $60.64 \%$ of the expressed variance. Factor $\mathrm{F} 1(47.58 \%)$ is determined by EC, hardness, alkalinity and $\mathrm{Cl}^{-}$, $\mathrm{Mg}^{2+}, \mathrm{Ca}^{2+}, \mathrm{HCO}_{3}^{-}, \mathrm{NO}_{3}^{-}, \mathrm{SO}_{4}^{2-}$ ions, as opposed to $\mathrm{Fe}^{2+}, \mathrm{NH}_{4}^{+}, \mathrm{NO}_{2}^{-}$and $\mathrm{I}^{-}$ ions. The elements which define this factor come from a long duration of solution following the water-rock contact. These elements come from the hydrolysis of minerals present in the rocks which constitute the bedrock of the aquifers which shelter the waters of the region. Indeed, hydrolysis being a slow process, factor F1 therefore expresses the phenomenon of mineralization-residence time. The grouping of the majority of the variables supported by mineralization, around this axis shows the influence of alteration-hydrolysis in the dissolution of ions. The presence of $\mathrm{NO}_{3}^{-}$on this axis reveals that the mineralization of water is accompanied by anthropogenic pollution. 

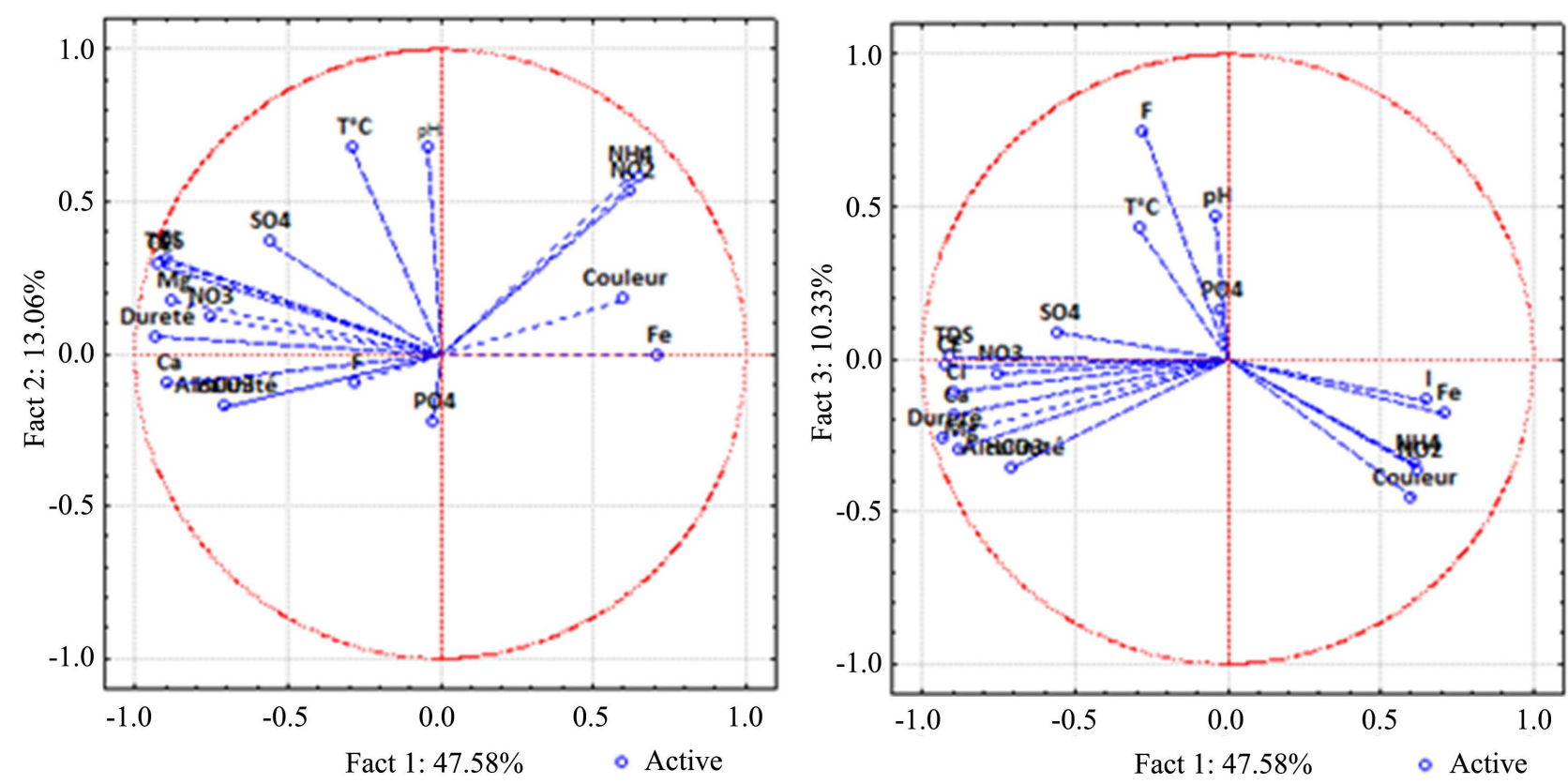

Figure 3. Analysis of variables in the factorial plane F1 - F2 and F1 - F3.

The opposite ions of $\mathrm{Fe}^{2+}, \mathrm{NH}_{4}^{+}, \mathrm{NO}_{2}^{-}$et I- drain the pole of colored waters rich in $\mathrm{Fe}^{2+}, \mathrm{NH}_{4}^{+}, \mathrm{NO}_{2}^{-}$et $\mathrm{I}^{-}$. Factors $\mathrm{F} 2$ and $\mathrm{F} 3$ respectively explain $13.06 \%$ and $10.33 \%$ of the inertia of the cloud of representative points of the structures and are determined by the temperature, the $\mathrm{pH}$ and the $\mathrm{PO}_{4}^{3-}$ and $\mathrm{F}^{-}$ions. Nitrogen compounds come from the degradation of organic matter by microorganisms in the surface layers of the soil, with the production of $\mathrm{CO}_{2}$ which is then carried away in depth with the seepage water (Ahoussi et al., 2008). Better still, the naturally occurring $\mathrm{NO}_{3}^{-}$ions which are part of the nitrogen cycle represent the most soluble form of nitrogen. Mainly used as inorganic fertilizers for plant growth and the synthesis of organic nitrogen compounds, excess nitrates can be found quickly in groundwater. Waste containing organic nitrogen also represents a source of nitrates obtained from various biochemical processes (ammonification and nitrification) (Aghzar et al., 2001; Amadou and al., 2014). This plan highlights the superficial exchanges that take place between the site's water and runoff from precipitation and soil drainage.

The graphic representation in space of the statistical units of the factorial plane F1 - F2 and especially F1 - F3 highlights three main groupings of water points (Figure 4). Class 1 gathers waters of medium to high electrical conductivity, the ionic acquisition of which is under the control of mineralization-residence time accompanied by anthropogenic pollution. Class 2 contains colored waters with high and natural concentrations of $\mathrm{Fe}^{2+}, \mathrm{NH}_{4}^{+}, \mathrm{NO}_{2}^{-}$and $\mathrm{I}^{-}$without anthropogenic input. These are waters with low electrical conductivity. Class 3 is much more distinct on the statistical units of the factorial plane F1 - F3. This class includes much more fluorinated and phosphated waters.

The Dendrogram (Figure 5) from the Ascending Hierarchical Classification (CAH) highlights three main groupings of variables. The 1st grouping consists 


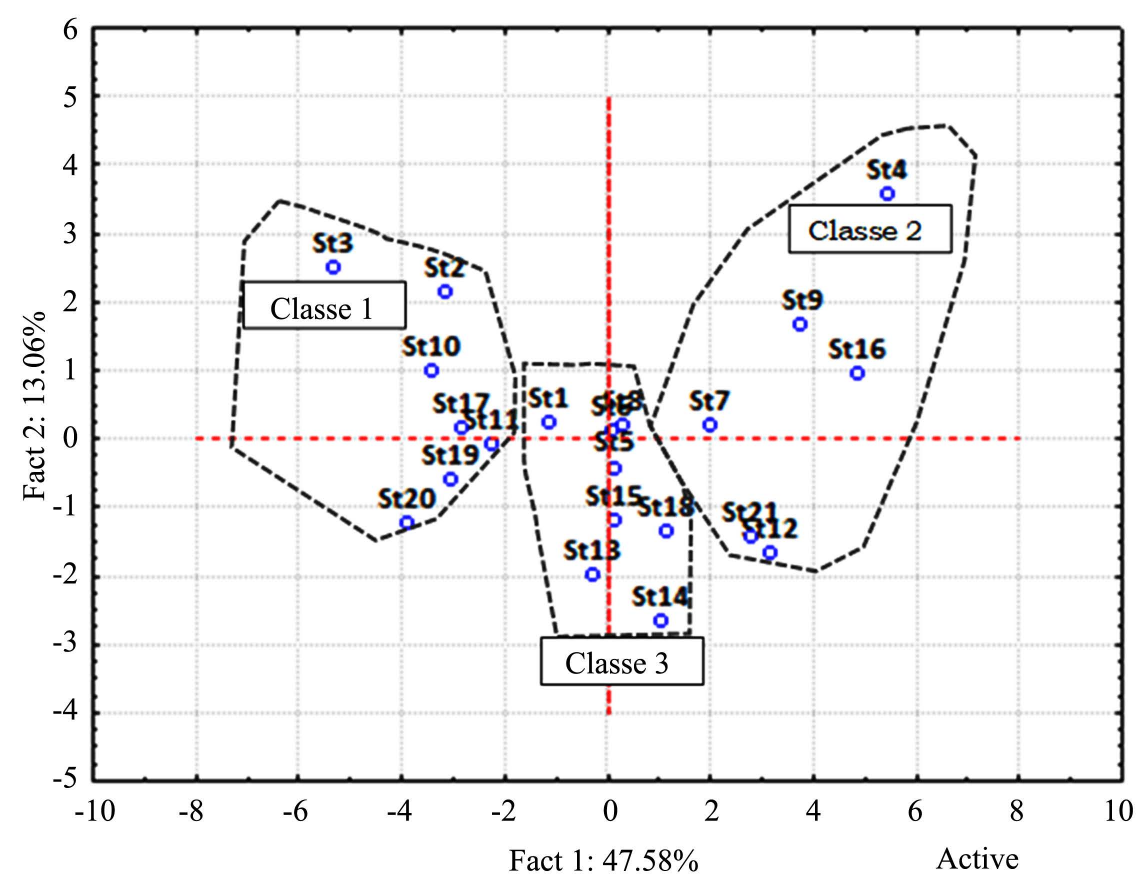

Figure 4. Space of the statistical units of the factorial plane F1 - F2.

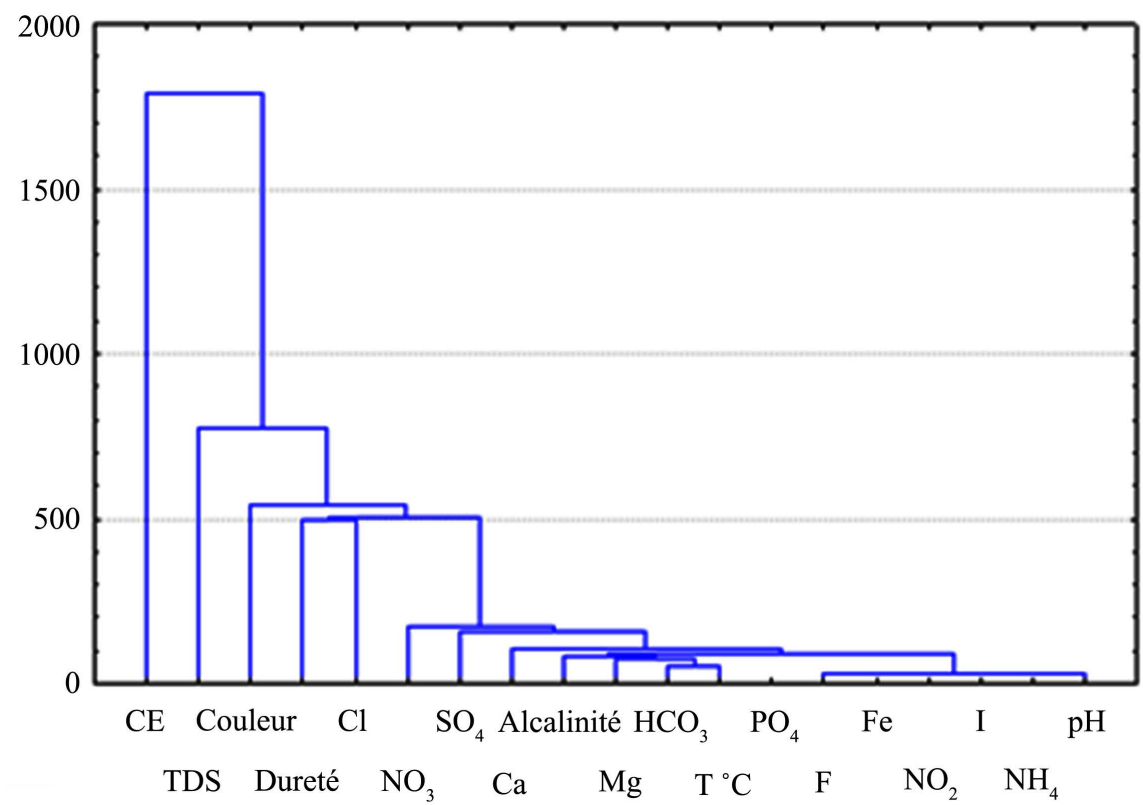

Figure 5. Dendrogram of the waters studied in the Hills department.

of CE, TDS and color. This group reports on the mineralization-residence time. The second group consists of chlorides and hardness. The 3rd group includes alkalinity, $\mathrm{HCO}_{3}^{-}, \mathrm{Ca}^{2+}, \mathrm{NO}_{3}^{-}, \mathrm{PO}_{4}^{-}, \mathrm{SO}_{4}^{2-}, \mathrm{Mg}^{2+}, \mathrm{F}^{-}, \mathrm{Fe}^{2+}, \mathrm{NH}_{4}^{+}, \mathrm{NO}_{2}^{-}, \mathrm{pH}$ and the temperature indicate the hydrolysis of minerals and the contribution of human activities in the mineralization of water from the study area. This group also highlights the phenomenon of mineralization governed by the infiltration of rainwater into aquifers. 


\subsection{Variation of $\mathrm{pH}$ and Temperature $\left(\mathrm{T}^{\circ} \mathrm{C}\right)$}

The $\mathrm{pH}$ of water provides information on its acidity and alkalinity. The $\mathrm{pH}$ of natural waters is generally between 6.6 to 7.8 (Nisbet et al., 1970) and it varies from 7.2 to 7.6 (Rodier, 1984). Usually, $\mathrm{pH}$ values are between 6 and 8.5 in natural waters (Chapman \& Kimstach, 1996). The nature of the land crossed by the water is the natural cause, causing significant variations in $\mathrm{pH}$. The analysis of these waters revealed that the $\mathrm{pH}$ is close to neutral, at the level of all the water points (Figure 6), the average $\mathrm{pH}$ values at the level of the study area were within the drinking water standards of groundwater (6.5 - 8.5 according to WHO standards).

Water temperature is an important factor in the aquatic environment as it governs almost all physical, chemical and biological reactions (Chapman \& Kimstach, 1996). In the study area, the measured temperature shows almost no variation (Figure 6). The observed value is around $29.5^{\circ}$. These values remain acceptable for drinking water standards.

\subsection{Study of the Spatial Distribution of Chemical Parameters}

The electrical conductivity of the water in the department of the hills varies from 56 to $1735 \mu \mathrm{S} / \mathrm{cm}$ for an average value of $612 \mu \mathrm{S} / \mathrm{cm}$. The low values of CE are observed in the localities of Soclogbo and Torto in the South-East and in Dame while the high values are observed in the localities of Yawa and Kpakpaza (Figure 7).

The spatial distribution of magnesium in this department shows values between 1.95 and $69.06 \mathrm{mg} / \mathrm{L}$ for an average value of $22.54 \mathrm{mg} / \mathrm{L}$. The low $\mathrm{Mg}$ values are observed in the localities of Soclogbo and Torto in the South-East and in Agbomadin, Dame, Missi, Logbo, Agbado and in Honnonkon while the high values are observed in the East of the localities of Yawa and Kpakpaza (Figure of Mg). Calcium varies from 4.81 to $97 \mathrm{mg} / \mathrm{L}$ for an average value of $46.03 \mathrm{mg} / \mathrm{L}$. The low $\mathrm{Ca}$ values are observed in the localities of Soclogbo and Torto in the south-east and west of the localities of Yawa and Kpakpaza while the high values are clearly observable in Gbedje, north of Karre and on both sides other from Ouedeme.
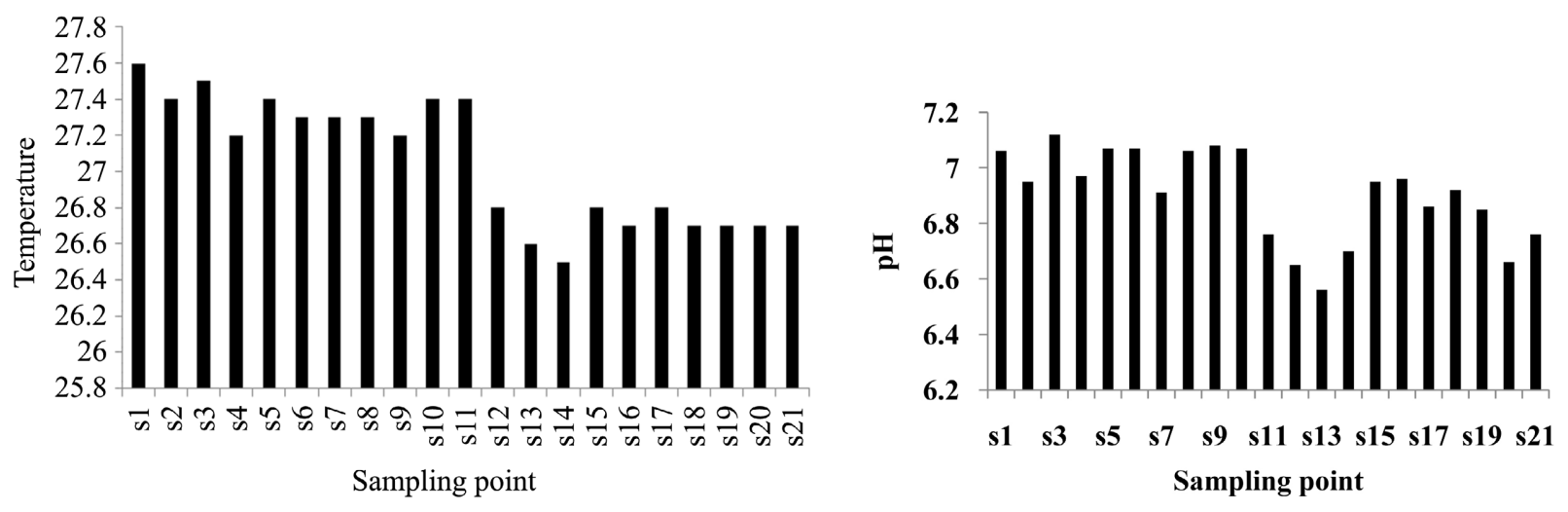

Figure 6. Variation in the $\mathrm{Ph}$ and temperature of groundwater in the Hills. 


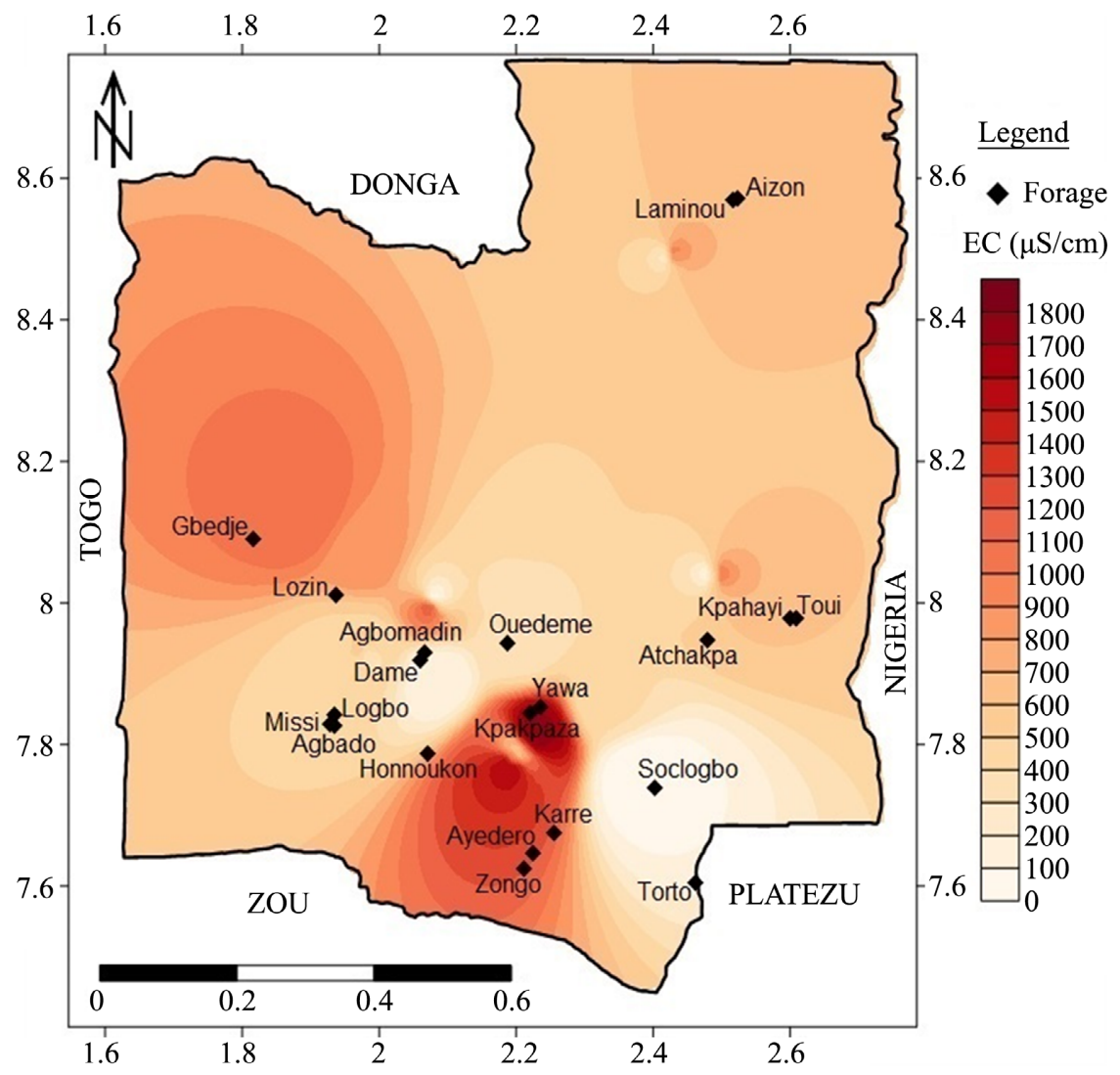

Figure 7. Spatial distribution of electrical conductivity.

It follows from variations in calcium and magnesium, a similar distribution with hardness, a function of $\mathrm{Ca}^{2+}$ and $\mathrm{Mg}^{2+}$. Then its values are between 24 and $498 \mathrm{mg} / \mathrm{L}$ with an average value of $208 \mathrm{mg} / \mathrm{L}$. As a result, groundwater is less hard in the localities of Soclogbo and Torto in the south-east while it is distinctly hard in Gbedje, west of Ouedeme, Yawa and Kpakpaza (Figure 8).

The alkalinity in the hills department shows values between 10 and $80 \mathrm{mg} / \mathrm{L}$ for an average value of $43.81 \mathrm{mg} / \mathrm{L}$. The low values of alkalinity are also observed in the localities of Soclogbo and Torto in the south-east while the high values are observed in the localities of Yawa and Kpakpaza (Figure 9).

The spatial distribution of chlorides in the department shows values that are between 14.2 and $335 \mathrm{mg} / \mathrm{L}$ for an average value of $134.89 \mathrm{mg} / \mathrm{L}$. The low values of $\mathrm{Cl}^{-}$are observed in the localities of Soclogbo and Torto in the south-east and in Dame, Missi, Logbo, Agbado and in Honnonkon while the high values are in Gbedje, Agbomadin and in Karre (Figure 10). With regard to fluoride ions, they vary from 0 to $1.1 \mathrm{mg} / \mathrm{L}$ for an average value of $0.49 \mathrm{mg} / \mathrm{L}$. Non-flowered waters are found in the localities of Soclogbo and Torto in the south-east and west of the localities of Yawa and Kpakpaza while those strongly fluorinated are clearly observed in the south of the localities of Atchakpa and Kpakpaza (Figure 10). It should also be noted that these values are lower than the WHO guide value which is set at $1.5 \mathrm{mg} / \mathrm{L}$. 

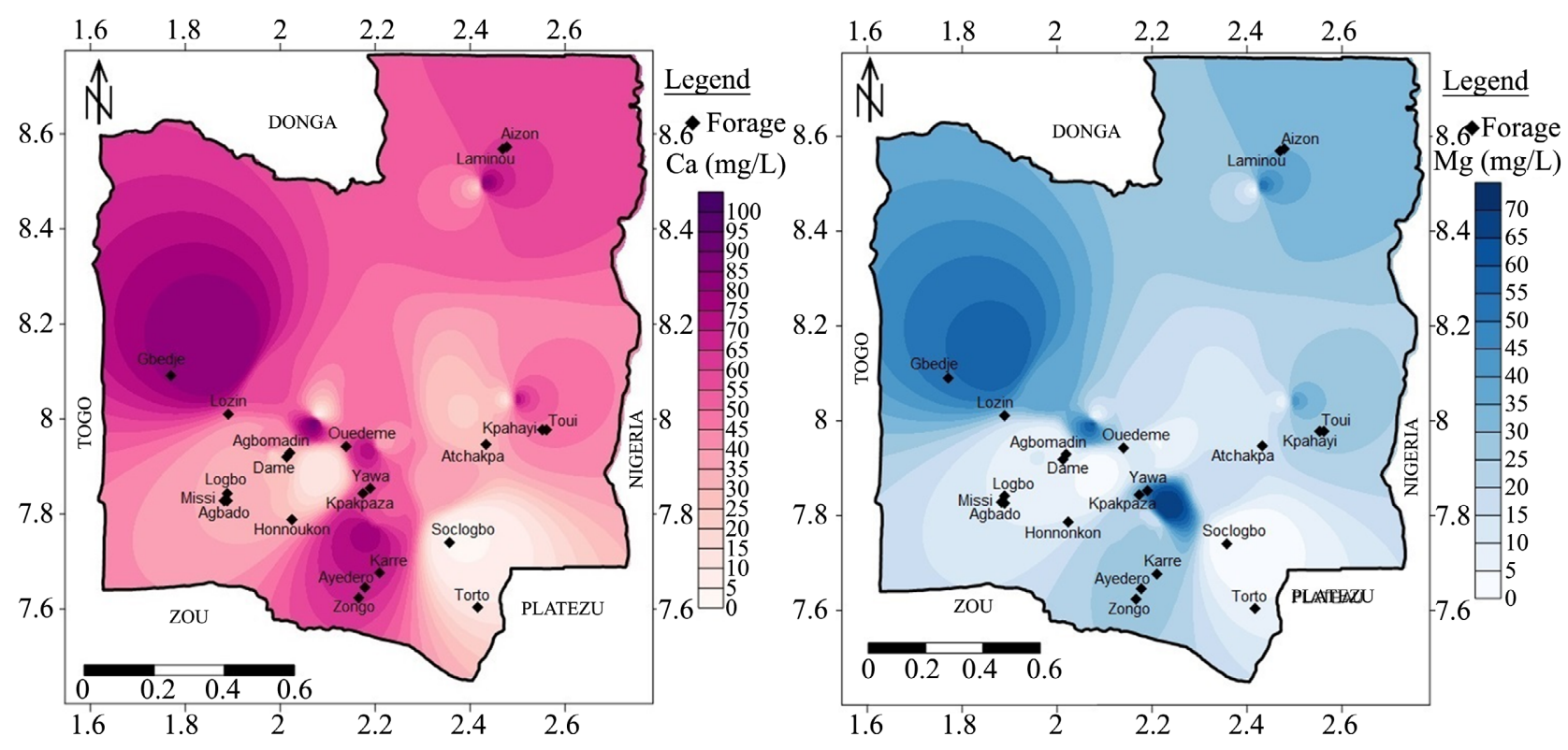

Figure 8. Spatial distribution of calcium and magnesium levels.
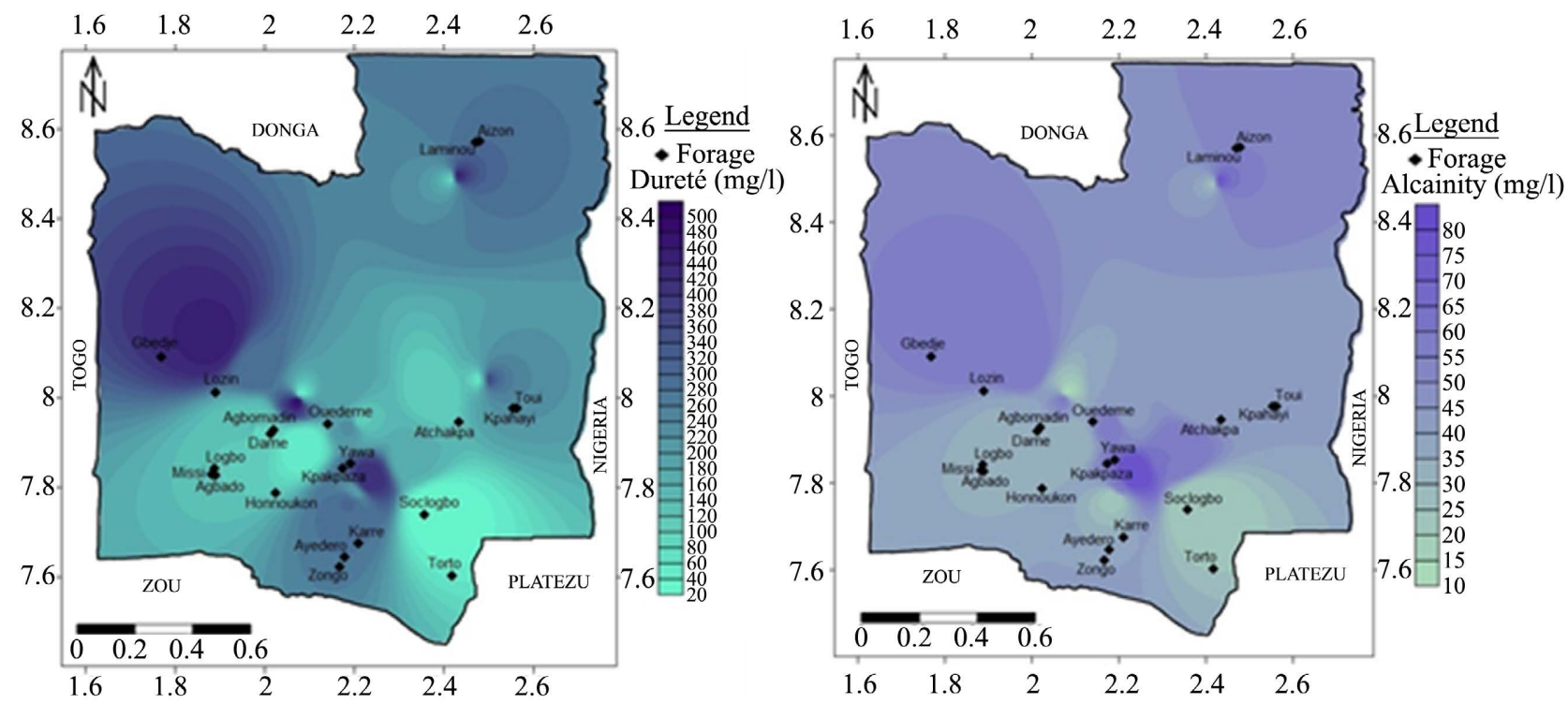

Figure 9. Spatial distribution of hardness and alkalinity rates.

For iodide ions, its values are between 0.09 and $2.09 \mathrm{mg} / \mathrm{L}$ with an average value of $0.39 \mathrm{mg} / \mathrm{L}$. The iodides are strongly observed in the localities of Soclogbo and Torto in the south-east and north-west of Ouedeme while its values are very low in the north and west in the department (Figure 11).

The spatial distribution of iron in the waters of the Collines department shows values which are between 0 and $1.25 \mathrm{mg} / \mathrm{L}$ for an average value of $0.28 \mathrm{mg} / \mathrm{L}$. Low Fe values are observed in the west and in the center of the department. High iron values are observed north of Honnoukon precisely between the localities of Agbomadin and Dame on the one hand and those of Yawa and Kpakpaza on the other hand (Figure 11). 


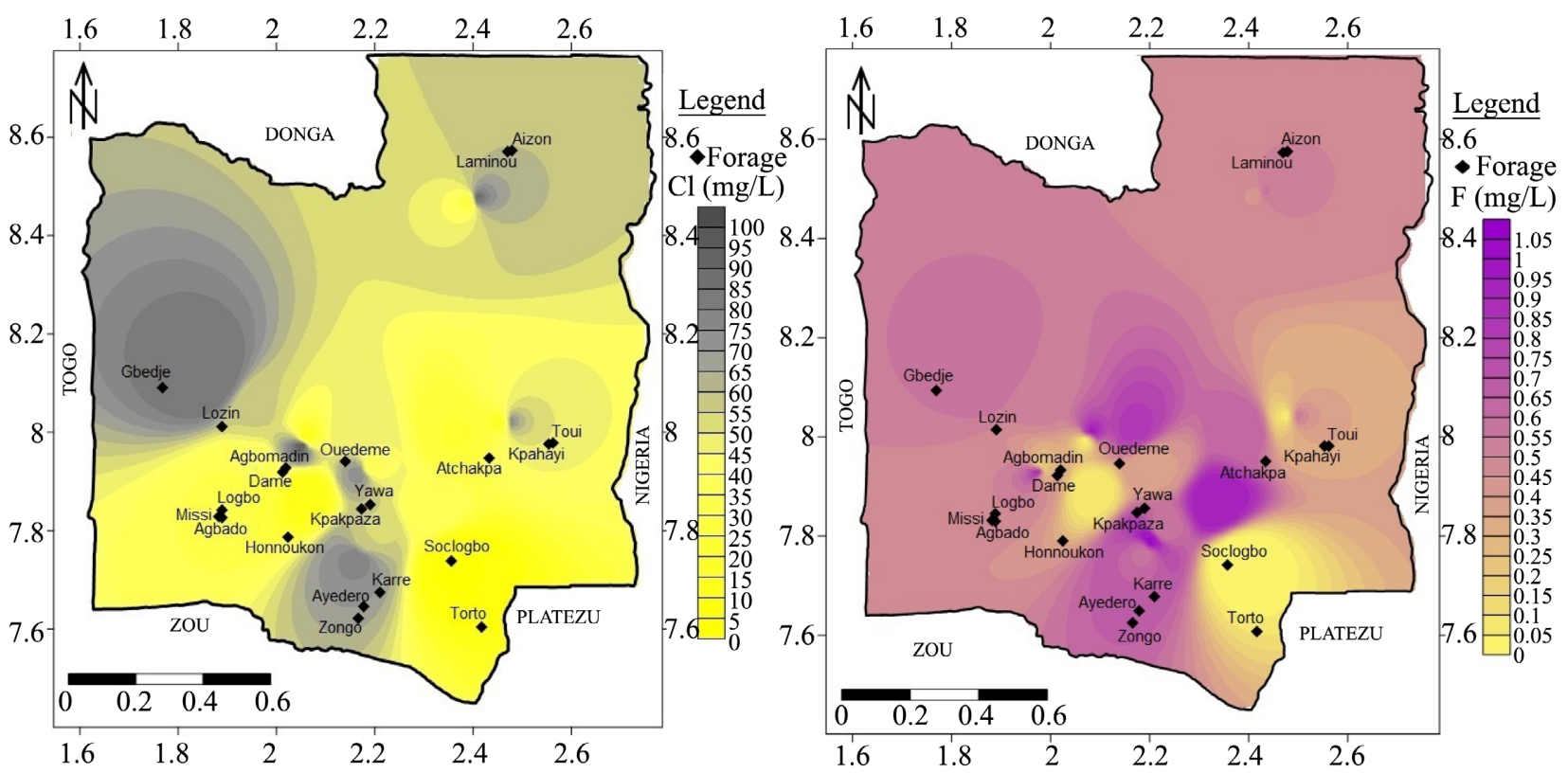

Figure 10. Spatial distribution of the levels of chlorides and fluorides.
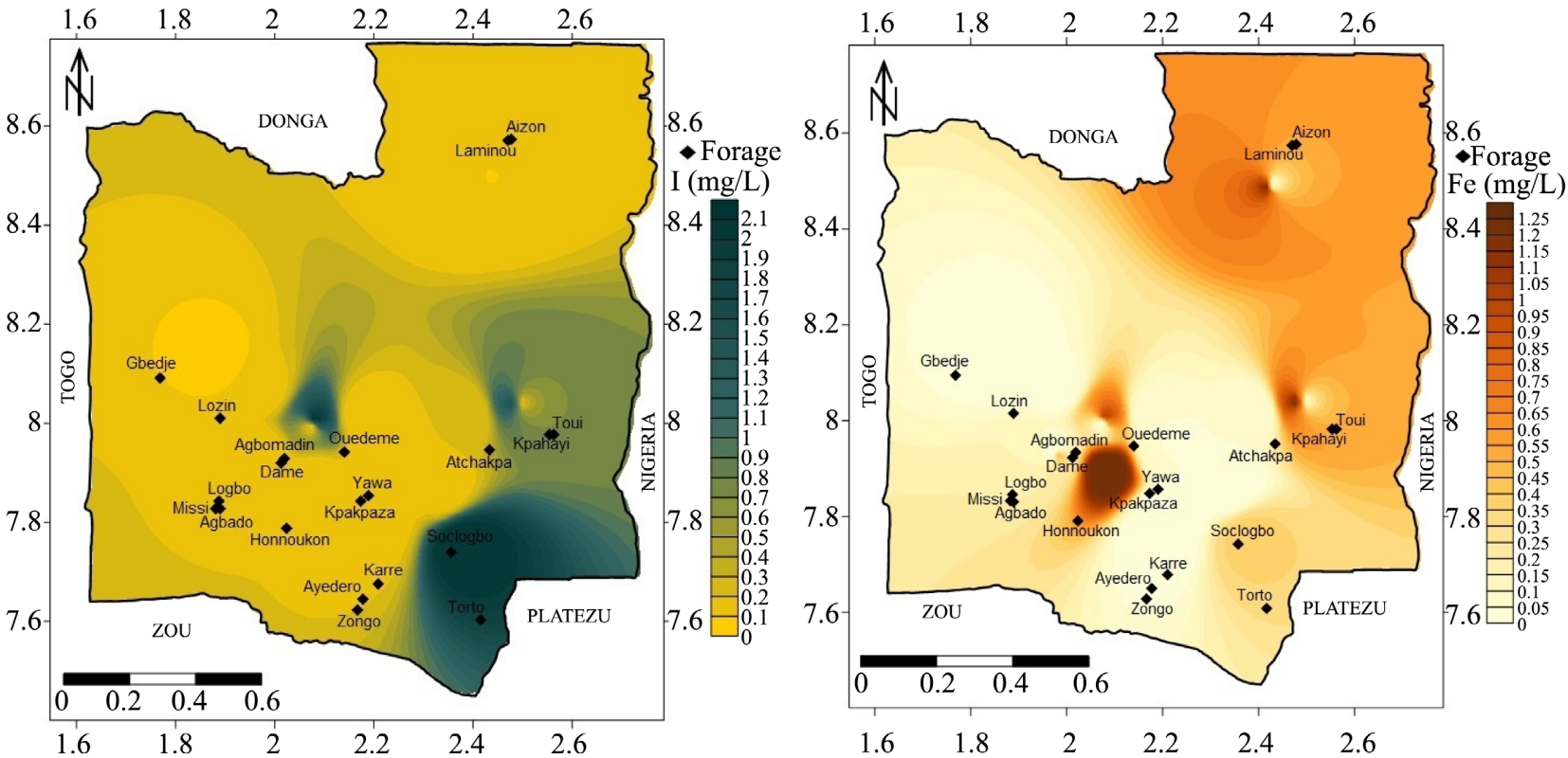

Figure 11. Spatial distribution of iodide and iron levels.

The bicarbonates in the waters of the department of the hills vary from 6.1 to $48.8 \mathrm{mg} / \mathrm{L}$ with an average value of $26.72 \mathrm{mg} / \mathrm{L}$. The low values of $\mathrm{HCO}_{3}^{-}$are observed in the localities of Soclogbo and Torto in the south-east while the high values are in the south-east of the localities of Yawa and Kpakpaza (Figure 12). The spatial distribution of ammonium in the department's groundwater shows values between 0 and $2.12 \mathrm{mg} / \mathrm{L}$ with an average value of $0.24 \mathrm{mg} / \mathrm{L} . \mathrm{NH}_{4}^{+}$values are high in the localities of Soclogbo and Torto in the south-east and almost zero in the localities of Gbedje and Lozin in the west of the study area and in the 


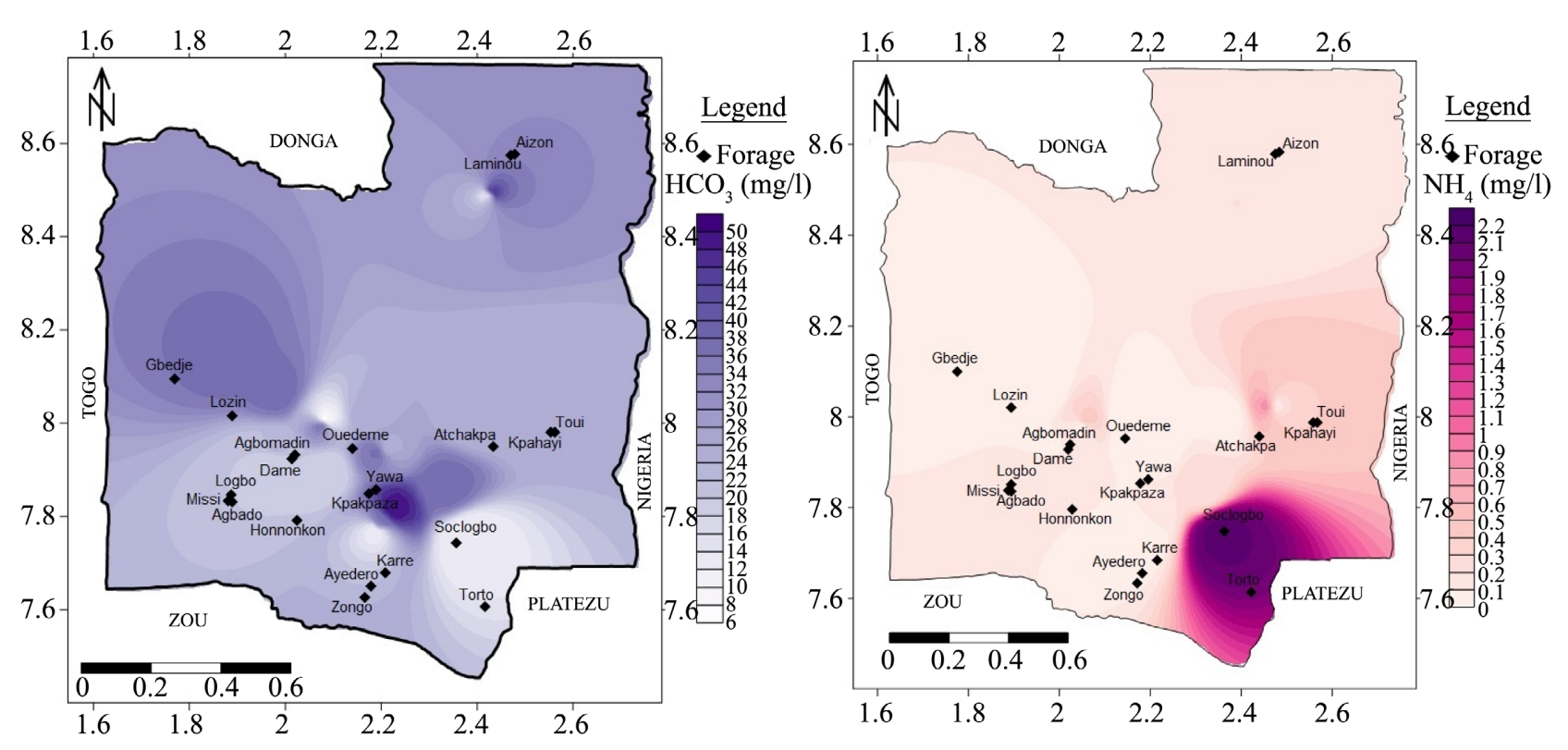

Figure 12. Spatial distribution of bicarbonate and ammonium levels.

center in the localities of Yawa, Kpakpaza, Karre, Ayedero, Zongo and Ouedeme (Figure 12).

Like ammonium, the spatial repair of nitrites is similar to it. Nitrites in the waters of the department are generally low with slightly higher values in the south-east, in the localities of Soclogbo and Torto. The values are between 0 and $0.27 \mathrm{mg} / \mathrm{L}$ for an average value of $0.03 \mathrm{mg} / \mathrm{L}$ (Figure 12). Unlike the two previous ions, nitrates are heterogeneous and vary between 0 and $163.91 \mathrm{mg} / \mathrm{L}$ for an average value of $53.07 \mathrm{mg} / \mathrm{L}$. The values of $\mathrm{NO}_{3}^{-}$are low in the South-East in the localities of Soclogbo and Torto or even Yawa, Honnoukon, Ouedeme, Agbomadin, Dame and Atchakpa. They are very high, exceeding the standard (50 $\mathrm{mg} / \mathrm{L}$ ) accepted by the WHO in the localities of Gbedje, Lozin, Missi and Logbo in the West, Aizon in the North-East, Karre and Zongo in the South of the zone d. study (Figure 13).

Phosphates in the waters of the Collines department are homogeneous and low throughout the department, with slightly higher values at the east of Ouedeme. The values are between 0.09 and $2.82 \mathrm{mg} / \mathrm{L}$ for an average value of 0.40 $\mathrm{mg} / \mathrm{L}$ (Figure 14). Regarding the sulfate ions, they vary from 0 to $128 \mathrm{mg} / \mathrm{L}$ for a mean value of $25.9 \mathrm{mg} / \mathrm{L}$. Waters very low in $\mathrm{SO}_{4}^{2-}$ are found in the localities of Soclogbo, Atchakpa and Torto in the south-east, while those strongly sulphated are clearly observed in the South in the localities of Yawa, Kpakpaza, Karre, Ayedero and Zongo (Figure 14).

\subsection{Assessment of the Quality of Drinking Water}

The quality of groundwater intended for consumption in the Hills was assessed following the study of the pollution parameters and the interpretation of a simplified grid (Table 3) namely the electrical conductivity and the chloride ions 
Table 3. Simplified grid for the assessment of the overall quality of groundwater.

\begin{tabular}{cccc}
\hline & \multicolumn{3}{c}{ Settings } \\
\cline { 2 - 4 } & \multicolumn{3}{c}{ Electrical Conductivity $\mu \mathrm{S} / \mathrm{cm}$ Chlorides $\mathrm{mg} / \mathrm{l}$ Nitrates $\mathrm{mg} / \mathrm{l}$} \\
\hline Excellent & $<$ to 400 & $<$ to 200 & $<$ to 5 \\
Good & $400-1300$ & $200-300$ & $5-25$ \\
Average & $1300-2700$ & $300-750$ & $25-50$ \\
Bad & $2700-3000$ & $750-1000$ & $50-100$ \\
Very bad & $>$ to 3000 & $>1000$ & $>100$ \\
\hline
\end{tabular}
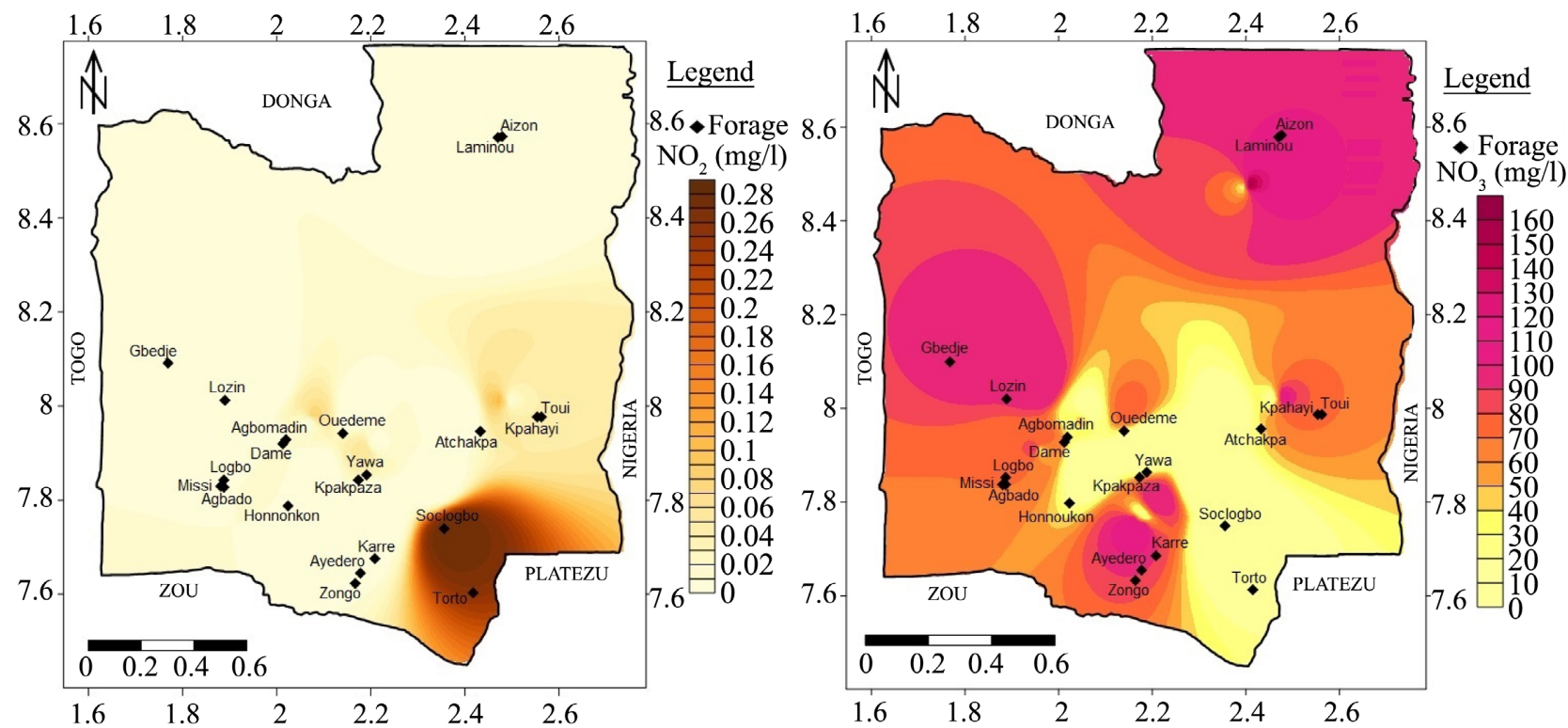

Figure 13. Spatial distribution of the rates of nitrites and nitrates.
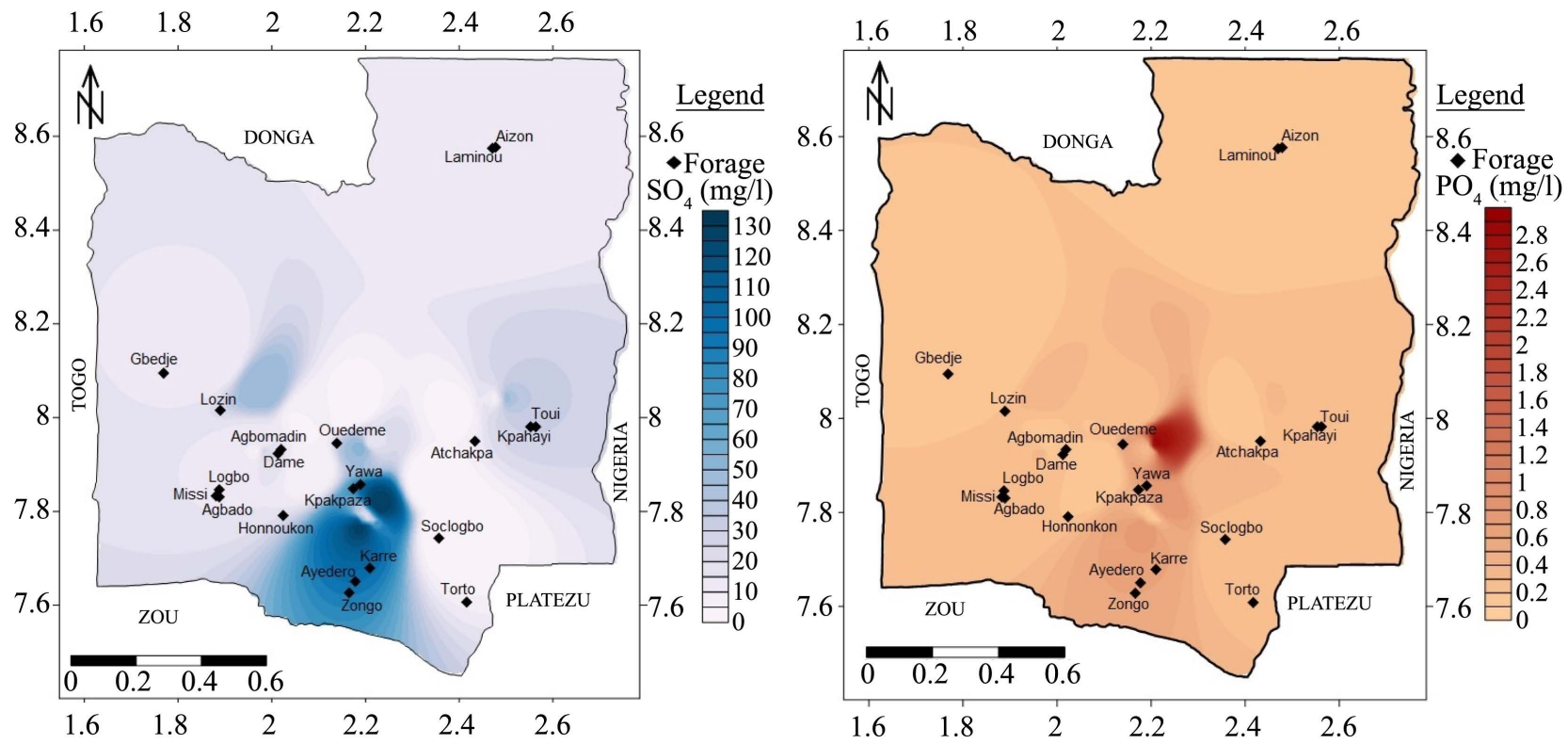

Figure 14. Spatial distribution of the levels of sulfates and phosphates. 
which provide information on the mineralogical quality of water then nitrates which are indicators of groundwater pollution (Nouayti et al., 2015).

Analysis of the samples has shown that the water quality is generally good or even excellent (Table 4). However, a cross-reading shows very poor-quality waters (zongo, toui and Aizon) of poor quality (karré, Missi, Logbo, Lozin, Ouédemè and Gbedjè) given the nitrate contents.

\section{Discussion}

The quality of water depends above all on its physicochemical parameters. The groundwater of the Collines Department is characterized by a neutral $\mathrm{pH}$ that meets WHO and Beninese standards for groundwater potability. These values are contrary to the values obtained in the municipality of Pobè (Lagnika et al., 2014) and in the district of Dêkin in Dangbo (Adéké, 2017), where they obtain acidic $\mathrm{pH}$ despite the significant presence of limestone in the area southern Benin. However, similar results have characterized the groundwater of Ulmès in Morocco (Dadi et al., 1997). The decomposition of organic matter in the surface layer of the soil produces the $\mathrm{CO}_{2}$ responsible for the acidity of groundwater in humid tropical environments (Ahoussi et al., 2010). The neutrality of the $\mathrm{pH}$ values obtained could therefore be linked to the nature of the geological formations made up of crystalline rocks, where certain rocks by dissociation in water release carbonate ions $\mathrm{CO}_{3}^{2-}$.

The $\mathrm{pH}$ of water depends on the temperature. The temperatures obtained are almost invariant and higher than the value allowed by the WHO standard. These values are slightly lower than those found by Lagnika et al. (2014), Adéké (2017) and Tossou (2016). The latter give this rise to the influence of the ambient temperature and by the geothermal gradient mentioned by Degbey et al., 2010 in Maoudombaye, 2015. The slight decreases in temperature observed in our study could be explained by the period and the time of sampling.

Table 4. Overall quality of groundwater in the hills.

\begin{tabular}{ccccccccccc}
\hline & $\mathrm{CE}$ & $\mathrm{Cl}^{-}$ & $\mathrm{NO}_{3}^{-}$ & Overall quality & & $\mathrm{CE}$ & $\mathrm{Cl}^{-}$ & $\mathrm{NO}_{3}^{-}$ & Overall quality \\
\hline Ayedero & 657 & 159.75 & 24.808 & GOOD & Lozin & 850 & 198.8 & 99.232 & GOOD \\
Zongo & 1574 & 298.2 & 119.61 & AVERAGE & Honnoukon & 147 & 46.15 & 0.886 & EXCELLENT \\
Karré & 1735 & 355 & 99.232 & AVERAGE & kpakpaza & 348 & 81.65 & 1.329 & EXCELLENT \\
Torto & 56 & 24.85 & 4.873 & EXCELLENT & Yawa & 388 & 49.7 & 7.531 & EXCELLENT \\
Soclogbo & 405 & 28.14 & 0 & EXCELLENT & Ouédemè & 399 & 60.35 & 72.652 & EXCELLENT \\
Missi & 532 & 110.05 & 98.346 & GOOD & kpabayi & 65 & 14.2 & 1.772 & EXCELLENT \\
Agbado & 323 & 106.5 & 34.554 & EXCELLENT & Toui & 1052 & 301.75 & 124.04 & GOOD \\
Logbo & 517 & 113.6 & 79.74 & GOOD & Atchakpa & 311 & 63.9 & 14.176 & EXCELLENT \\
Agbomadin & 57 & 35.5 & 1.772 & EXCELLENT & Gbedjè & 1046 & 227.2 & 95.942 & GOOD \\
Damé & 1198 & 284 & 45.186 & GOOD & Aizon & 983 & 227.2 & 163.91 & GOOD \\
& & & & & Laminou & 207 & 46.15 & 24.808 & EXCELLENT \\
\hline
\end{tabular}


Groundwater has an average electrical conductivity in accordance with the standard. These values are higher than those recorded in the municipality of Pobè by Lagnika et al. (2014) $236.62 \mu \mathrm{S} / \mathrm{cm}$ on average, as well as that obtained by Adejuwon and Mbuk in Ikorodu in Nigeria. This comparison shows that the waters of the department of hills are mineralized.

The ions responsible for the mineralization of water can be of natural or anthropogenic origin; the concentration of magnesium $\left(\mathrm{Mg}^{2+}\right)$ and calcium $\left(\mathrm{Ca}^{2+}\right)$ ions determines the hardness of the water. It is $22.54 \mathrm{mg} / \mathrm{L}$ on average for magnesium and $46.03 \mathrm{mg} / \mathrm{L}$ for calcium. The latter lead to a hardness of $208 \mathrm{mg} / \mathrm{L}$ on average. It follows from these results that the water in the hills is moderately hard. But, the different concentrations of $\mathrm{Mg}$ and Ca comply with the WHO and Beninese standard. By comparison, the recorded magnesium concentration is higher than that of water from wells in the commune of Pobè $(13.63 \mathrm{mg} / \mathrm{L})$, water from boreholes in the village of Dêkin $(0.17 \mathrm{mg} / \mathrm{L})$ in the commune of Dangbo (Adéké, 2017). According to Oga $\mathrm{Ca}^{2+}$ and $\mathrm{Mg}^{2+}$ ions could come from basic magmatic rocks, more or less metamorphosed. The significant presence of $\mathrm{Mg}^{2+}$ ions in the groundwater of the Collines department may be of natural origin, because their soil is made up of migmatitic and gneissic rocks intruded by granitic plutons in circumscribed massifs and a volcano-sedimentary series (Breda, 1989; Adissin, 2012).

The anions associated with these cations are $\mathrm{Cl}^{-}, \mathrm{I}^{-}, \mathrm{SO}_{4}^{2-}, \mathrm{HCO}_{3}^{-}$, chloride ions are strongly present with average concentrations of $134.89 \mathrm{mg} / \mathrm{L}$ but located below the standards admissible by WHO. The concentration of sulfate ions is $25.9 \mathrm{mg} / \mathrm{L}$ on average. There is a low content of fluoride ions $(0.49 \mathrm{mg} / \mathrm{L})$. All these values meet the standards for the quality of drinking water. The concentration of chlorides recorded in this study exceeds that obtained in the groundwater of Pobè (17.75 - $7.26 \mathrm{mg} / \mathrm{L}$ ) (Lagnika et al., 2014), in the groundwater of Dêkin (6.3 mg/L) (Adéké, 2017) as well as that obtained by Dadi in 1997 (11.15 - 24 $\mathrm{mg} / \mathrm{L}$ ) in the aquifers of the crystallophyllian Massif of Oulmès (Morocco), Aka et al. (2013) $(33.33 \mathrm{mg} / \mathrm{L})$ in the department of Abengourou (south-east of the Ivory Coast). The significant presence of chloride ions could be of anthropogenic origin because the water table is fed from the surface by rainfall recharge (Kamagaté, 2006; Kamagaté et al., 2007; El-Fahem, 2008; Kamagaté et al., 2008).

The alkalinity of water is the concentration of carbonate, bicarbonate and hydronium ions it contains. It is $43.81 \mathrm{mg} / \mathrm{L}$ on average. The average concentration of bicarbonate in groundwater in the department of hills is $26.72 \mathrm{mg} / \mathrm{L}$. This value is lower than that obtained by Lagnika et al., (2014) $(37.87 \mathrm{mg} / \mathrm{L})$ in the boreholes of the municipality of Pobè, Dadi et al., $1997(23.13-192 \mathrm{mg} / \mathrm{L})$ in the water underground of the Ulmès plateau and its surroundings in Morocco. This observed difference confirms the neutral nature of the groundwater in the department of hills. The $\mathrm{pH}$ being neutral, the concentration of hydronium ions is equal to that of hydroxide, which leads to an average concentration of 17.09 $\mathrm{mg} / \mathrm{L}$ of carbonate ions $\left(\mathrm{CO}_{3}^{2-}\right)$ responsible for the neutralization of its acid 
coming from the decomposition of organic matter in the surface layer of the soil (Ahoussi et al., 2010).

The Collines department in Benin is a region recognized for its agricultural activity which is based on the misuse of chemical fertilizers and pesticides to increase agricultural yields. This constitutes a danger for the quality of groundwater caused by the presence of nitrogenous derivatives (nitrite, nitrate, ammonium, phosphate). These waters are characterized by an average concentration of $0.24 \mathrm{mg} / \mathrm{L}$ of ammonium ion, $0.03 \mathrm{mg} / \mathrm{L}$ of nitrite ion and $53.07 \mathrm{mg} / \mathrm{L}$ of nitrate ion and $0.40 \mathrm{mg} / \mathrm{L}$ of phosphate ion. Generally speaking, these values comply with WHO and Beninese standards except for nitrate which is above standards. This nitrate value is higher than that found by Adéké (2017) $(1.5 \mathrm{mg} / \mathrm{L})$ in the district of Dêkin, Lagnika et al. (2014) $(45.30 \mathrm{mg} / \mathrm{L})$ in the town of Pobè as well as that obtained by Oga (2009) $(0-10 \mathrm{mg} / \mathrm{L})$ in the Tiassalé region in Côte d'Ivoire, Dadi, 1997 (1.48 - $36.17 \mathrm{mg} / \mathrm{L})$ in the crystallophyllian massif of Oulmès (Morocco). This significant presence of nitrate confirms the oxygenation of the medium which ensures the transformation of ammonium ions into nitrates. The latter reaches the groundwater by filtration and may be the main factor in the deterioration of the quality of these waters (Aghzar et al., 2002). This pollution of groundwater in the department of hills by nitrates comes from human activities of agricultural origin. Likewise, the fairly high levels of total nitrogen in organic matter could also have an impact on the vulnerability of the water table to this pollution.

Iron is a trace element beneficial to the body at low concentrations. Its content in groundwater in the hills is $0.28 \mathrm{mg} / \mathrm{L}$ on average, below the norm. But it appears more at the level of Zoumè with contents higher than the standard. This value obtained is lower than the value recorded in the Tiassale region in Côte d'Ivoire (1.38 - $8.75 \mathrm{mg} / \mathrm{L})$ by Oga et al. (2009), in the district of Dêkin commune of Dangbo in Benin (5.49 mg/L) by Adéké (2017). The latter as well as the results of Ahoussi et al. (2013) attach the high iron content of drilling water to the ferralitic nature of the more or less leached soil. The soil of the region of the hills of Benin not being ferralitic, the presence of iron in the groundwater at this polluted point could be of anthropogenic origin because it is fed by rainfall recharge from the surface. Indeed, according to Oga, iron gives water an unpleasant metallic taste, and a reddish brown color. The coloring of the water obtained in the area is then due to the presence of iron. This statement is confirmed by the analysis of variables which shows a correlation between colored water and $\mathrm{Fe}^{2+}$ ions.

\section{Conclusion}

This study made it possible to assess the quality and potability of underground water resources in the hills. The analyzes carried out on twenty-one (21) drinking water points are carried out on physical (temperature, $\mathrm{pH}$ and electrical conductivity) and chemical (cations and anions) parameters. The results showed 
that the $\mathrm{pH}$ of water depends on the temperature; the values of these two parameters are higher than those of the WHO unlike those of the electrical conductivity which conform to it. The water sampled is highly mineralized in $\mathrm{Mg}^{2+}$ ions. These ions are suspected of natural origin. The strong presence of $\mathrm{Cl}^{-}$and especially $\mathrm{NO}_{3}^{-}$ions (a very good indicator of the vulnerability of aquifers) makes it possible to suspect the presence of derivatives of phytosanitary products and pesticides in drinking water. These products cause toxicity in the consumer. Likewise, the relatively high total nitrogen content of organic matter could also have an impact on the vulnerability of the water table to this pollution. It is urgent to conduct a study of the biological quality of its sampling sites to target localities exposed to a health risk. This study thus reveals the non-drinkability of water resources in the hills.

\section{Conflicts of Interest}

The authors declare no conflicts of interest regarding the publication of this paper.

\section{References}

Adéké, A. M. H. (2017). Analyse des dépôts issus des eaux souterraines par la spéciation Commune de Dangbo (77 p.). Mémoire de master.

Adissin Glodji, C. L. (2012). La zone de cisaillement de Kandi et le magmatisme associé dans la région de Savalou-Dassa (Bénin): Etude structurale, pétrologique et géochronologique (276 p.). Thèse de Doctorat, Université Jean Monnet Saint-Etienne.

Afouda, F. (1990). L'eau et les cultures dans le Bénin central et septentrional: Etude de la variabilité des bilans de l'eau dans leurs relations avec le milieu et la savane africaine (428 p.). Thèse de doctorat nouveau régime, Paris IV, Sorbonne.

Aghzar, N., Bellouti, H., \& Soudi, B. (2001). Pollution nitrique des eaux souterraines au Tadla (Maroc). Revue des Sciences de l'Eau, 15, 459-492.

https://doi.org/10.7202/705465ar

Aghzar, N., Berdai, H., Bellouti, A., \& Soudi, B. (2002). Pollution nitrique des eaux souterraines au Tadla (Maroc). Revue des sciences de l'eau, 15, 459. https://doi.org/10.7202/705465ar

Ahoussi, E. K., Soro, N., Kouassi, A. M., Soro, G., Koffi, Y. B., \& Zade, S. P. (2010). Application des méthodes d'analyses statistiques multivariées à l'étude de l'origine des métaux lourds $\left(\mathrm{Cu}^{2+}, \mathrm{Mn}^{2+}, \mathrm{Zn}^{2+}\right.$ et $\left.\mathrm{Pb}^{2+}\right)$ dans les eaux des nappes phréatiques de la ville d'Abidjan. International Journal of Biological and Chemical Sciences, 4, 1753-1765. https://doi.org/10.4314/ijbcs.v4i5.65537

Ahoussi, K. E., Koffi, Y. B., Kouassi, A. M., Soro, G., \& Biemi, J. (2013). Étude hydrochimique et microbiologique des eaux de source de l'ouest montagneux, Cote d'Ivoire. Journal of Applied Biosciences, 63, 4703-4719. https://doi.org/10.4314/jab.v63i1.87245

Ahoussi, K. E., Soro, N., Soro, G., Lasm, T., Oga, M. S., \& Zadé, S. (2008). Groundwater Pollution in African Biggest Towns: Case of the Town of Abidjan (Côte d'Ivoire). European Journal of Scientific Research, 20, 302-316.

Aka, N., Bamba, S. B., Gbombele, S., \& Soro, N. (2013). Étude hydrochimique et microbiologique des nappes d'altérites sous climat tropical humide: Cas du département d'Abengourou (Sud-Est de la Côte d'Ivoire). Larhyss Journal, 16, 31-52.

Amadou, H., \& et Abdou Salam Manzol, M. S. L. (2014). Application des méthodes 
d'analyses statistiques multivariées à l'étude de la minéralisation des eaux de la zone de Zinder (Sud-Est du Niger). International Journal of Biological and Chemical Sciences, 8, 1904-1916. https://doi.org/10.4314/ijbcs.v8i4.50

Azonsi, F., Alé, G., \& Cougny, G (2009). Processus de gestion intégrée des ressources en eau au Bénin, Rapport d'étude (21 p.).

Boko, M. (1988). Climatologie et communautés rurales du Bénin; Rythmes climatiques et rythmes de développement (608 p.). Thèse de doctorat d'Etat ès-lettres à l'Université de Bourgogne Dijon.

Bokonon-Ganta, B. E. (1987). Les climats de la région du Golf du Bénin (Afrique de l'Ouest) (226 pages + Annexes). Thèse du doctorat de troisième cycle en climatologie; Université de Paris IV-SORBONNE.

Boukari, M. (1982). Contibution à l'étude hydrogéologique des régions de socle de l'Afrique Intertropicale: l'Hydrogéologie de la région de Dassa-Zoumé (Bénin) (173р.). Thèse de doctorat de 3ème cycle en Géologie Appliquée, mention Hydrogéologie, Université de Dakar (Sénégal).

Boukari, M. (2007). Hydrogéologie de la République du Bénin (Afrique de l'Ouest). Africa Geoscience Review, 14, 303-328.

Breda (1989). Notice explicative de la carte géologique à 1/200000 (77p.). Feuilles Pira-Savè, Abomey-Zagnanado, Lokossa-Porto-Novo.

Chapman, D., \& Kimstach, V. (1996). Selection of Water Quality Variables. In Water Assessment: A Guide to the Use of Biota, Sediments and Water in Environment Monitoring, Chapman Edition (pp. 59-126, 2nd ed.). E \& FN Spon.

Dadi, S., Laziri, M. F., Demassieux, L., \& Dassargues, A. (1997). Etude hydrochimique d'un aquifère en milieu fissuré: Cas du Massif cristallophyllien d'Oulmès (Maroc). Proceedings of Rabat Symposium S2, May 1997.

Dubroeucq, D. (1967). Etude des sols de la région ouest Dassa-Zoumé: Carte pédologique au 1/50 000è (172 p.). Office de la Recherche Scientifique et Technique Outre-Mer-Centre de Cotonou.

El-Fahem, T. (2008). Hydrogeological Conceptualisation of a Tropical River Catchment in a Crystalline Basement Area and Transfer into a Numerical Groundwater Flow Model-Case Study for the Upper Ouémé Catchment in Benin (178 p.). Thèse de Doctorat, Universität Bonn.

Houssou, C. S. (1998). Les bioclimats humains de l'Atacora (Nord-Ouest du Bénin) et leurs implications socioéconomiques (332 p.). Thèse de doctorat de l'université de Bourgogne, centre de Recherche de Climatologie, Dijon.

Jain, P., Sharma, J. D., Sohu, D., \& Sharma, P. (2005). Chemical Analysis of Drinking Water of Villages of Sanganer Tehsil, Jaipur District. International Journal of Environmental Science and Technology, 2, 373-379.

Kamagaté, B. (2006). Fonctionnement hydrologique et origine des écoulements sur un bassin versant de milieu tropical de socle au Bénin: Bassin versant de la Donga (Haute Vallée de l'Ouémé) (320p.). Thèse de Doctorat, Université Montpellier II.

Kamagaté, B., Seguis, L., Favreau, G., Seidel, J. L., Descloitres, M., \& Affaton, P. (2007). Processus et bilan des flux hydriques d'un bassin versant de milieu tropical de socle au Bénin (Donga, haut Ouémé). Comptes Rendus Geoscience, 339, 418-429.

https://doi.org/10.1016/j.crte.2007.04.003

Kamagaté, B., Seguis, L., Gone, D. L., Favreau, G., \& Koffi, K. (2008). Processus hydrogéochimiques et séparation d'hydrogrammes de crue sur un bassin versant en milieu soudano-tropical de socle au Bénin (Donga, Haute Vallée de l'Ouémé). Revue des 
Sciences de l'Eau, 21, 363-372. https://doi.org/10.7202/018782ar

Lagnika, M., Ibikounle, M., Montcho, J.-P. C., Wotto, V. D., \& Sakiti, N. G. (2014). Caractéristiques physico-chimiques de l'eau des puits dans la commune de Pobè (Bénin, Afrique de l'ouest). Journal of Applied Biosciences, 79, 6887-6897. https://doi.org/10.4314/jab.v79i0.13

Mangin, A. (1970). Contribution à l'étude d'aquifères karstiques à partir de l'analyse de courbes de décrue et de tarissement. Annales de Spéléologie, 25, 581-609.

Méhounou, J. P., Jossé, R. G., Dossou-Yovo, P., Sènou, S. F., \& Toklo, R. M. (2016). Caractérisation physico-chimique et microbiologique des eaux souterraines et superficielles dans la zone de production cotonnière d'Aplahoué. Journal of Applied Biosciences, 103, 9841-9853.

Nisbet, M., Verneaux, J., \& Paris, C. (1970). Composantes chimiques des eaux courantes: Discussion et proposition de classes en tant que bases d'interprétation des analyses chimiques. p. 161-190. https://doi.org/10.1051/limn/1970015

Nouayti, N., Khattach, D., \& Hilali, M. (2015). Evaluation de la qualité physico-chimique des eaux souterraines des nappes du Jurassique du haut bassin de Ziz (Haut Atlas central, Maroc) Assessment ofphysico-chemical quality of groundwaterof the Jurassic aquifers inhigh basin of Ziz (Central High Atlas, Morocco). Journal of Materials and Environmental Science, 6, 1068-1081.

Oga, M.-S., Lasm, T., Yao, T. K., Soro, N., Saley, M. B., Kouassi, D., \& Gnamba, F. (2009). Caractérisation chimique des eaux des aquifères de fracture: Cas de la région de Tiassalé En Côte d'Ivoire. European Journal of Scientific Research, 31, 72-87. http://www.eurojournals.com/ejsr.htm

Ogouwalé, E. (2006). Changement climatique dans le Bénin méridionale et central: Indicateurs, scenarios et perspectives de la sécurité alimentaire (320 p.). Université d'Abomey-Calavi.

Rodier, J. (1984). L'analyse de l'eau: Eaux naturelles, eaux résiduaires, eaux de mer. Edition Dunod Paris.

Rodier, J. (2009). L'analyse de l'eau (9th éd., p. 1579). DUNOD (éditeur).

Tossou, Y. Y. J. (2016). Caractérisation des anomalies fluorées des eaux souterraines $d u$ socle Précambrien de la partie centrale du Bénin (Afrique de l'Ouest): Apport des outils hydrogéochimiques, pétrographiques et minéralogiques (181p.). Thèse de doctorat, Université de Liège.

World Health Organization (1981). Contemporary Patterns of Breast-Feeding: Report on the WHO Collaborative Study on Breast-feeding. World Health Organization. 211 p. https://apps.who.int/iris/handle/10665/40079

World Health Organization (2006). The World Health Report. 237p. 